\title{
WHEN CULTURE IS HARMFUL
}

\section{Mate Maskhulia}

Master of Public Administration, University of Bergen, Department of Administration and Organization Theory. Address: 17/19 Christies Gt., 5007 Bergen, Norway.

E-mail: masskhulia@gmail.com

\begin{abstract}
This article is based on mixed-method research conducted into the Georgian public administration system. The author of the article studied Georgian public administration from the perspective of sociocultural theories. The study proposed and confirmed the hypothesis that the persisting issues in Georgian public administration have deep cultural implications which originated from unchangeable centuries-old traditions of local society. With that, the study disproves the common opinion that corruption arose in local managerial traditions primarily during the soviet period. Besides, the results of the study revealed that a new generation of Georgian public servants in some matters demonstrate more traditionalism than their senior colleagues. At the same time, data analysis exposed a subgroup of Georgian bureaucrats which might be considered as potential modernizers among homogeneous groups of cultural traditionalists. Overall, the author makes the conclusion that models of behaviour which are assessed in Western societies as corrupt, are legalized and approved in Georgian society, as well as in local public office.
\end{abstract}

Keywords: Georgia, bureaucracy, public administration, reforms, culture, corruption, nepotism, cronyism, informal networks.

Citation: Maskhulia, M. (2021). When Culture is Harmful. Public Administration Issues, no 5 (Special Issue I, electronic edition), pp. 107-136 (in English). DOI: 10.17323/ 1999-5431-2021-0-5-107-136

\section{Introduction}

Despite long-term reforms, Georgian public administration is still considered as a corrupt system. The main features of Georgian public office are patronclient relations, power abuse, nepotism, cronyism, creation of informal networks, inability of teamwork, clanship, and non-transparency (Charkviani, 2014, p. 5). These phenomena appear during in-group and out-group relations. As a result of this corrupt public office, currently Georgia has "an ineffective and unprofessional bureaucracy which experiences difficulties even in the execution of its basic 
functions" (Rukhadze, 2016). Both Georgian and foreign researchers associate the issues of Georgian public administration with the legacy of its soviet past. According to this view, Soviet nomenklatura ${ }^{1}$ performed as a "spoiler" of Georgian bureaucracy (Shelley et al., 2007; Charkviani, 2014; Dolidze et al. 2010). However, researchers do not present distinct evidence which may indicate the implication of the Soviet epoch to the current issues in Georgian public office.

Thus, the objective of this article is to fill the gap in the scientific knowledge by uncovering the causes of continuous corruption in Georgian public administration which persists even in spite of large-scale reforms. Another aim of the article is to dispute common scientific opinion of the "soviet origination" of corruption in local public administration. Rather, the author brings to the fore the "sanctum sanctorum" of Georgian society - its proudly cherished cultural traditions. At the same time, the article puts in doubt the opinion of the cultural homogeneity of Georgian bureaucracy. Vice versa, the author seeks cultural variability among public servants as a result of generational change and large-scale reforms. Thus, the main purpose of the article is to detect certain dynamics inside an allegedly uniform system.

\section{The Significance of cultural prospect}

The literature argues that public entities, despite the adoption of formal rules, reflect the values and norms existing and practised in society (Hofstede, 2005; Alvesson, 2002). Accordingly, cultural context is a factor that determines the efficiency of performance of any organization (Jamil, 2007). Cultural prospect might be understood as an integral "conceptual toolkit" for the study and analysis of a system of modern organization (Morrill, 2008, p. 15). Jamil argues that organizations which are studied through a cultural prism differ not only across cultures but also within one society (Jamil, 2007). Thereby, the performance of an organization that inevitably consists of agents of different values should be analysed through a humanistic approach that focuses on the cultural context of interacting subjects (Alvesson, 2002). These views contradict the view of proponents of the "mechanistic" "one best way-approach" (e.g. Fayol, Taylor, Weber), who argued for the study of organizations through the prism of formal rules (Jamil, 2007). On the contrary, as practise shows, "one-size-fits-all", which originated at the turn of the twentieth century, has proved its scientific inefficiency (Persson et al., 2013, p. 466). According to observations, cultural traditions play a significant role in the life of Georgians in determining relationships, both on societal (informal) and public (formal) levels. However, reasonable doubt exists as to whether Georgian societal culture has a positive influence in the matter of establishing an efficient public office. At the same time, the literature argues that every cultural tradition should be considered as an impermanent variable that tends (in the case of certain circumstances) to change (Fukuyama, 2011, p. 437; Putnam, 1993, p. 180). According to this notion, cultural traditions are

\footnotetext{
1 "Nomenklatura" is a patrimonial model of Soviet bureaucracy which was based on loyalty and obedience to the hierarchy of Communist party functionaries.
} 
not timeless and static, but they are continuously being influenced by economic, political, social and historical factors (Ekiert \& Hanson, 2003; Meyer-Sahling et al., 2011). Therefore, despite interrelation between corruption and societal culture in developing countries, researchers, at the same time, reject branding societal cultures of developing nations as entirely corrupt. They argue that national culture might be considered as much "a culture against corruption" as it is "a culture of corruption" (Smith, 2007). The same deliberated approach may be applied in the context of Georgia with consideration of the abovementioned politico-economic and socio-historical factors. However, in the case of Georgia it was still an unanswered question to what side - "culture against corruption" or "culture of corruption" - members of Georgian society lean more to, especially the new generation of Georgians. On the basis of these assumptions, three main research questions were formulated:

1. Is it possible to say that the issues of Georgian public administration and its permanent inability to transform into a Western model of public office are determined by local societal traditions?

2. Is Georgian bureaucracy homogeneous (i.e. traditional) in its cultural attitudes or is it possible to single out "modernizers" among Georgian public servants?

3. Which variables, if any, determine the modernity of Georgian public servants?

\section{The structure of Georgian public administration}

The literature considers bureaucracy through several categories: branch of government (executive, legislative, judiciary), types of positions (low, medium, high), place of work (central level, field level), and nature of work (generalist, specialist) (Jamil, 2007, p. 98). According to Georgian law on public service adopted in 1997, there are four categories of public employees in Georgia: (1) public-political officials, (2) public servants, (3) supplementary staff, and (4) freelance/supernumerary workers (Dolidze et al., 2010). Public employees of different categories can perform either at central governmental level or local governmental level. Georgian law on public service formulates several requirements concerning employment policy that public organizations should stick to. According to the law, recruitment of employees in Georgian public organizations should occur on the basis of either election or appointment. Conforming to the legal regulations, most Georgian public employees are appointed to their positions. These are public servants (or office workers), supplementary staff (or technical workers), and freelance/supernumerary staff, i.e. temporary employees engaged either in office work or the technical provisions of the organization. These types of public employees must be appointed to their positions on the basis of a contest that proves their professional qualification and competence. At the same time, supplementary staff might be hired by governmental structures in the case of a need for their expert knowledge. As for public-political officials, such types of public employees are divided into two categories: (1) political officials who are elected, and (2) public officials who are appointed to the position either by elected political officials or by an authorized department of public organization (e.g. HR department) (ibid: p. 115). 


\section{Criteria of "a good bureaucracy"}

Weber's concept of bureaucracy, which has been formally adopted in Georgian public administration, considers public office as a rational-legal system. According to Weber, the ideal type of bureaucracy consists of ten characteristics which place bureaucracy into a legal framework, at the same time, restricting it from gaining and abusing power (Albrow, 1970, p. 45). The Weberian model implies meeting the following requirements: (1) appointment on the basis of contract, (2) observation of solely impersonal duties in the offices, (3) selection on the basis of professional qualification, (4) legal mechanisms of career promotion, (5) existence of a unified control and disciplinary system in the organization, (6) observation of hierarchy, (7) specified mechanisms of office function, (8) granting salary according to holding position, (9) non-misappropriation of resources related to the office, and (10) public office as a major occupation (ibid). Some criteria of ideal Weberian bureaucracy, such as strict discipline and control by means of an administrative hierarchy, may contradict the contemporary perception of efficient public administration. However, "good bureaucratic functioning", according to the modern approach, still implies the observation of such basic requirements as the selection of public employees on the basis of their professional qualification and promotion on the basis of merit rather than through personal informal relations (Fukuyama, 2014, p. 59).

Georgian public office supposedly contradicts Weber's concept of rational bureaucracy in key parameters. Firstly, Georgian public servants are not subordinated to their superiors merely on the basis of a formal hierarchy. Secondly, Georgian bureaucrats are not selected or promoted on the basis of their professional qualification, they are rather appointed on the basis of personal connections. Thirdly, in Georgian public entities, observation of formal intra-organizational business etiquette is disregarded as personal relations are put to the forefront but not professional interests (Charkviani, 2014, p. 5, pp. 122-180). Accordingly, the Georgian system of public administration opposes the Weberian concept of bureaucracy in its ideal (rational-legal) understanding appearing as a patron-client system. Such type of public office implies a contractualconventional model of organization and performs without any well-thought-out strategy, neglects formal requirements, but focuses on the informal relations (Cassese in della Porta et al., 1999, p. 133). Moreover, clientelistic bureaucracy represents a risk for the efficient performance of public administration (Fukuyama, 2014, p. 87).

\section{Georgian societal traditions: some facts}

Qualitative research attempts to find parallels between issues of Georgian public administration and local societal traditions. Referring to the existing scientific data (Charkviani, 2014, p. 5, pp. 122-180), under the "issues of Georgian public administration", the following were considered: (a) persisting phenomena of power concentration, (b) patron-client relations, (c) clan system, (d) inability of teamwork, and (e) overall insusceptibility to reforms. 


\section{Culture of Domination and Subordination}

In contemporary Georgia, social hierarchy manifests on two dimensions: on a macrosocial level (interactions between different social stratums) and a microsocial level (interpersonal interactions and interactions of groups from the same social stratum). Relationships on both dimensions are characterized by superiority of more authoritative either groups or individuals over either less powerful groups or less powerful individuals. At the same time, local political elites, which belong to the highest social stratum in Georgia, are also subordinated - to international political and business elites (Gotsiridze, 2014; Maisashvili, 2016). Patronclient relations existing between local and international elites are explained by the historical subordination of the Georgian state to foreign invaders (Shiukashvili, 2010). On the other hand, patron-client relations between local elites and representatives of lower social stratums refer to the heritage of undeveloped civil society which historically facilitated social division and elitist relations between classes. As for the microsocial (intragroup) level, hierarchy is caused by societal norms that refer to (a) patriarchal traditions, (b) perception of leadership as domination, and (c) tradition of affiliation to influential societal groups that endow individual authority over less affiliated ones. Establishment of superiority as a main principle of relations between social groups and individuals has created in Georgia a cultural phenomenon of subordination to the holder of power, whether that is a single individual (e.g. elder, father, leader, etc.) or individuals (e.g. priest, businessman, public official, etc.) which represent influential groups (e.g. church, company, government, etc.). Such socio-historical "tuning" has developed in contemporary Georgian society subjugating models of interrelation (Bichikashvili, 2017; Berdzenishvili, Maisashvili, 2016; Gotsiridze, 2014; Shiukashvili, 2010).

Another cultural regularity is an upbringing method which might be associated with the tradition of "nurturing of tyrants" (i.e. dominating and powerful men). According to local traditions, the upbringing of youngsters aims at the formation of "persistent, purposeful and courageous man who will strive for the best results in everything" (Toria, 2015, p. 98). Such youngsters are educated to be in competition mode throughout life. From their childhood, youngsters seek success and domination over their peers. Parents foster boys' interests in physical activity and competitions; victories are complimented, while defeats are perceived as painful failures. The upbringing of girls implies acquiring skills related to maintaining the household and service to other members of the family (ibid). Hierarchy of local families implies a patriarchal order: subordination of women to men, children to parents, juniors to seniors. As to methods of education, in local families these are based on (a) persuasion, (b) authority, (c) encouragement and (d) punishment. At the same time, there is a lack of dialog between family members (Smirnova, 1983; Semyonova, 2011; Tsiramua, 2015). Scholars note that subordination in Georgian families is an agreed phenomenon which is accepted by family members themselves. Thus, the majority of Georgian women do not protest their subordinate status but rather expect domination from the males.

The survey shows that $56 \%$ of Georgian females believe that a wife should obey her husband even if she does not agree with him (UNDP, 2013). Psychologists argue that Georgian society lives according to a double moral: behaviour 
that is forgivable for men (strong) is unforgivable for women (weak). In such conditions, relationships between Georgian men are generally reduced to continuously proving their masculinity to each other. If one cannot prove his superiority, he tries to dominate in another situation among other (even unknown) people; otherwise, the man loses self-esteem and is labelled as an insolvent male, i.e. subordinate or marginal male (Nikoleishvili, 2014). Overall, Georgians want to be on the side of winners and not to stand among the losers in the crowd. The aspiration to be part of a successful and dominating group (i.e. power) is instilled in Georgian children by their parents from childhood.

\section{Georgian Collectivism: "We" and "They"}

Georgian society is a collectivistic society, however, Georgian collectivism has its peculiarities. Esebua argues that Georgian society is a narrowly collectivist society which perceives as a collective only particular referent groups. Consequently, the Georgian version of collectivism is accompanied by nepotism and other forms of favouritism. Esebua writes that the societal tradition of narrow collectivism is reflected also in the business environment: "in Georgia being pleasant for referent group is much more important than professionalism, and for such referent group one's loyalty is more important than his qualification" (Esebua, 2016). Nizharadze echoes that Georgian culture is collectivistic and it is oriented on the creation of small groups. Such groups consist of several hundred men and women who know each other personally. These people might be relatives, friends, acquaintances, and to a lesser degree colleagues, neighbours, distant acquaintances; i.e. those who share the same values, norms of behaviour, and interests. Basically, all those who can be united under the words "My" and "Our" (Nizharadze, 2015). There are a few factors that determine the prevalence of narrow collectivism in Georgian society. These factors are: (1) norms of social relations arising from the tradition of upbringing youngsters; (2) postulates of orthodox religion and its oppressive traditions that do not contribute to the formation of individualism among congregations; (3) historical factors such as (a) centuries-old division of nation by principalities and (b) historical inability of civic organizations (Nizharadze, 2014; Shelley et al., 2007). Moreover, a paradoxical phenomenon exists in Georgia: despite enormous hardships that face most of the locals, there are neither civil solidarity nor organized protest in society, but there is a persistent tradition of division on "we" ("my family", "my yard", "my friends", "my schoolmates", etc.) and "they" (strangers, aliens, rivals, foes) on both societal and political levels. The tradition of division on "we" and "they" is skilfully used by local government, which usually explains the failure of its policies by the intrigues of the external enemies of Georgian state. Thus, there is always a universal pretext that the Georgian authorities use as an excuse for inefficient domestic policy, and Georgian society accepts it. Apparently societal acceptance is conditioned by an inherent distrustful attitude of Georgians towards strangers that is a part of a cultural code of the nation (Bichikashvili, 2017).

One of the explanations for the alienation to strangers is the tradition of upbringing in Georgian society. According to this tradition, representatives of a new generation are kept within the family and the circle of their out-of-group communication is limited by senior relatives. As a result of such isolation inside families, 
youngsters are influenced and dependent on parents in both financial and moral aspects (Mkheidze, 2010). Ermisch et al. argue that social conservation of youngsters inside families and absence of outward exposure inhibit trust in strangers. Subsequently, in adulthood, intrinsic attachment to familiar settings and familiar personalities stimulate the creation of the features of narrow collectivism that impact the ability to form out-of-group relationships. Conversely, those who have a weaker attachment to their families demonstrate higher levels of trust in strangers. The motivation for the establishment of a wide range of social networks is a need for social interaction and the pursuit of economic welfare (Ermisch et al., 2010).

It should be noted that it is exactly the family circle where centuries-old traditions of communication are preserved and transmitted to new generations. As Majundar argues, "without the family there could be no preservation of the species and culture" (Majundar in Dawa, 2002, p. 235). Thus, even soviet collectivism which sought to subdue the mindset and behavior of Soviet citizens could not break the traditional structure of Georgian family. Gellner writes that after the onset of Soviet collectivism, which opposed old cultural norms, the institute of family became the concentration point of societal traditions in newly communist Georgia. As a result, pre-communist societal traditions, religious beliefs, kinship ties, and overall "national consciousness" were concentrated in the private sector (Gellner \& Simon in Dawa, 2002). As Rakowska-Harmstrone notes, in the Soviet Union the concept of a well-tied family became the factor which eventually preserved societal traditions and the feeling of the ethnic identity of nations united during several decades under the motto of Soviet collectivism (ibid).

Another meter of social cohesion is an index of prevalence of individual interests over collective interests (Hofstede, 2005). According to Georgian societal tradition, individual interests have always been placed lower than the interests of the family which is traditionally managed by an effective head. At the same time, interests of the family have always been placed higher than the collective interests of the neighbourhood or village. Such a system of prioritization of interests might be considered as one of the most persistent manifestations of narrow collectivism in Georgian society.

\section{Mental Dilemma: Between Mythology and Reality}

According to the literature, there are two factors which determine dynamics of institutional changes of society: firstly, it is an extent of traditionalism of society, and, secondly, it is an extent of rationality of those traditions. Irrationally, traditional society is characterized by either absence or low dynamics of institutional changes. Moreover, such society subordinates individuals' intellectual and social initiatives to the authority of traditions. Consequently, instilled traditions give life to social stereotypes which contradict the concept of rationality and ultimately prevent society from further development (Weber, 1992). According to Lippmann, social stereotypes, as a synonym of irrational societal traditions, represent "pictures in our heads" which in most cases do not reflect reality. Such a distorted "picture of reality" gives an inaccurate impression on the surrounding world, at the same time, preventing the adoption of new information (Lippmann, 2004). In Georgian society, the contrast between traditional stereotypes and mod- 
ern ideas is distinctively observed. Despite being part of the European political space, Georgian culture rejects Western values; consequently, norms and principles that are common for Western mentality hardly take root in Georgian society (Antonova, 2017). A mismatch of the form with its content has occured in Georgia for decades. Thus, the Bertelsmann Transformation Index (2016) reports that since the early 1990s in Georgia, the copying of democratic institutional values which are applied in Western societies has occurred. Those values were brought to Georgia by Western experts without consideration of local cultural specifications; as a result, their implementation has failed. Overall, the principles of Western democracy formally adopted by the Georgian state as a role model were developed by people who bore a different cultural code (Antonova, 2017).

Social stereotypes stem from existing cultural beliefs, values and orientations which are instilled in a human being from childhood. Thereby, stereotypes refer to the subconscious level which determines individuals' behaviour. The essence of stereotypes manifests in simple division on "mine-not mine", "friend-enemy" and "goodbad", which implies blind adherence to instilled traditions. One of the probable explanations for the ingrained traditionalism of Georgian society is centuries of occupation by foreign invaders. Thus, during foreign invasions, rejection of something new, i.e. something that comes from outside, was equal to resistance and, at the same time, preservation of national identity. In modern Georgia, attempts at the introduction of liberal ideas usually cause conflict between different social groups. According to experts, two worldviews exist in Georgia today: modern and traditional. The modern worldview is based on the prevalence of Western liberal values which seek institutional and social changes; those values are promoted mostly by non-governmental organizations which are backed by Western NGOs. The traditional worldview is focused on the past, creating and rooting social stereotypes. The main sources of stereotypes are the ideology of the church, chauvinism of local intellectuals, and populism of politicians (Nizharadze, 2015; Bichikashvilil, 2016).

The enormously increased role of the Orthodox church in recent years and decades has formed a new type of closed, intolerant, narrow collectivist group in Georgia that consists of "homogeneous congregation" and clergy having "supreme and indisputable authority" (Nizharadze, 2015). The institute of the church instils congregation episodes from the "glorious past" and ideas of a divine nature of Georgian nation in its congregations. At the same time, the church does not teach any rational skills of creative intergroup relations and critical comprehension of surrounding reality. Rather, the Georgian orthodox church performs as an assistant of the authorities in the "taming" of the masses with the motto "be patient on the Earth, the better life is waiting for you there in Heaven" (Bichikashvili, 2016). Mariamidze notes that the doctrine of the Georgian orthodox church is akin, no more and no less, to "fascism". "Division of human beings by first-rate and second-rate, condemnation of idea of equality, promotion and justification of segregation and discrimination, intimidation by conspiracy theories, - these and many others are the methods of education of congregation", Mariamidze says (2014). As a result of such ideological "processing", Georgian society represents a deeply neophobic society which is inclined to traditions and highly appreciates its "glorious past" (Bichikashvili, 2016). Having different vectors, nevertheless, 
myths in Georgian society have one distinct feature - exaltation of self-importance and representation of Georgia as a "little empire" with a unique heritage (Maisuradze, 2015). Mindiashvili (2014) acknowledges that one of the sources of intolerance in Georgian society is religious philosophy that promotes irrational ideas of isolationism and national exceptionalism.

Another area where religious views play an obstructive role is the attitude towards labour. Being one of the main institutes of socialization, religion is considered as a factor which determines economic behaviour and habits of social actors (Zabaev, 2008, p. 57). In this regard, the doctrine of protestant philosophy has played a significant role in the development of capitalism, the rationalization of the economy and business, taking care of creditworthiness and the culture of long-term investment. At the same time, Georgian orthodox Christians tend to interpret the concept of labour as a labour of spirit depreciating other possible interpretations of the concept. Specifically, Georgian orthodoxy opposes the concept of materially rewarded hard work which is one of the main principles of Western Christianity that has become its fundamental religious value (Nizharadze, 2015). According to Georgian orthodox Christians, the crowning achievement of labour is religious enlightenment rather than material success (Kachkachishvili, 2014). "Orthodox religion is not oriented on mundane life because it is associated with mysticism, with the transcended world (Mindiashvili, 2014, p. 10). Socio-economic identification of orthodox Georgians can be expressed in the following theses: "We are special people" and "We labour to live" (Nizharadze, 2015). This contradicts the Western religious philosophy that can be expressed as "We live to labour" that implies individual initiatives and the progressive improvement of quality of either product of the labour or work conditions.

\section{Failure of public administration reforms as a cross-national issue}

Arasli and Tumer explain cross-national similarities by the concept of microgeographies that refers to similarities in the sociocultural evolution of nations. Thus, nepotism and other forms of favouritism might have identically occurred in societies which are similar in their cognitive development (Arasli \& Tumer, 2008). Hofstede also proclaims similarity of historical background as a central factor of cross-cultural affinity which determines the formation of values and social institutes of nations (Hofstede, 2005, p. 323). According to Pavlova, commonalities of values and cross-national affinity result from similarities of nations in such aspects as historical background, societal traditions and religious identity (Pavlova, 2014). Antonova acknowledges that similarity of guiding ideas of different societies are formed through identical socio-historical backgrounds. Those ideas being developed through centuries take the form of fundamental political, economic and cultural axiospheres of modern societies (Antonova, 2017).

Greece, as a country with the same socio-historical features as Georgia (one religion, centuries-old subordination to foreign rulers), faces the same challenges in its system of public administration. Papadoulis writes that the main distinctive features of Greek public office are clientelism, patronage and corruption. He argues that in modern Greek public administration there is a gap between formally adopted 
EU policy and informal practices which manifest in disobedience of formal norms and statutes. According to him, negligence of formal rules by Greek public employees impacts on the morality and legality of the whole system of local public administration. "The Greek public administration system and style is not a reflection of its formal, institutional context. It has been conditioned by a variety of informal and non-institutional behaviors and practices" (Papadoulis, 2006, pp. 13-16). Papadoulis writes that the adoption of all-European legal standards of bureaucratic performance was supposed to be a guardian of improvements to Greek public administration contributing to its transparency and legalism. However, new legislation in the hands of inadequate implementers failed. Papadoulis argues that, nowadays, Greek public administration, despite formally adopted European legislation, is entirely incompatible to key characteristics of the Weberian public administration archetype; according to him, those characteristics are: calculability, efficiency, instrumentality, and legal rationality or legitimacy. The failure of Greek public administration is explained by multidimensional factors: (1) prevalence of private interests of public actors, (2) current political objectives, (3) national culture and style of administration, and (4) socio-economic needs, demands and problems (ibid). Thus, factors that impact the efficiency of public administration in Greece might be divided on modern economic and historical socio-cultural factors. Accordingly, processes and phenomena which take place on both administrative and political levels in Greece refer to either specific economic or cultural factors.

In writing about the problem of clientelism and patronage in Greek public administration, Papadoulis refers to a socio-cultural factor: "Clientelism, patronage and corruption represent a significant part of Greek society's behavior, nature, attitude and overall relationships" (Papadoulis, 2006, p. 13). He argues that during reforms of Greek public administration that represented replication of EU legislation, there was no consideration of informal non-institutional structures and practices existing in Greece. Consequently, a study of informal non-institutional structures and practices of Greek society would uncover algorithms through which clientelism, patronage and corruption are maintained and even expanded in local public administration. According to Papadoulis, currently any policy implementation in Greece is filtered by the national administrative system that employs patronage and clientele practices. This might be explained by attitudinal and behavioral loyalty to corruption on a political level in Greece. On the other hand, the problem of acceptance of clientelism, patronage and corruption might refer to a deeper noninstitutional level which concerns local society's "cultural and politico-economic traditions and ideologies" (Papadoulis, 2006, p. 21). Thus, according to Papadoulis, "the degeneration of the ethical, transparent and legal environment in which public servants operate has been eased by a climate of tolerance, a mafia omerta and impunity... The propensity to tolerate clientelism, corruption and patronage in particular, is closely related to the appraisal of individual or affinity groups' self-interest and selfishness in Greek society... This allows such practices to flourish and expand, threatening the values underpinning democracy" (ibid).

In studying public administration in Western and Eastern Europe, MeyerSahling et al. (2011) note that it is a fallacy to disregard a variety of local traditions and historical legacies. Those varieties are in direct relation with, on the one 
hand, institutional resilience, and, on the other hand, institutional persistence that either assist the adoption of reforms or hinder them. Consequently, for successful implementation of "universal" policies there should be common similarity across countries, such as "national-political administrative history, culture, traditions and styles of governance" (Meyer-Sahling et al., 2011). Therefore, in the process of transformation of the post-communist administrative system which is characterized by over-politicization and weakness of formal rules into Western-style, administration attention should be paid first of all to institutional reforms. “... studies that focus on the causal effects of the past reach remarkably similar conclusions regardless of their geographical focus: legacies are primarily seen as a reform inhibiting factor" (Meyer-Sahling et al., 2011, p. 313). According to Ekiert and Hanson (2003), the concept of legacy might be analyzed according to three temporal prospects. Those prospects refer to the interaction of three temporal factors: (a) pre-communist cultural and historical context, (b) communist administrative heritage developed during the Soviet epoch, and (c) post-communist epoch that refers to the period of transformation and adoption of Western, i.e. new, administrative traditions (Ekiert \& Hanson, 2003, p. 19). As Meyer-Sahling et al. (2011) note, collective analysis of three temporal dimensions of concept legacy contributes to better comprehension of ideas, values, institutions and practices existing in society, as well as providing information about actors and their attitudes.

Normally, the concept of legacy is associated with the concept of path-dependence, which implies analysis of compatibility of formal rules with existing societal norms. Accordingly, the extent of either prevalence of formal rules or informal practices among interacting subjects might be explained by the historical socio-cultural norms of society (North in Putnam, 1993). The central role of socio-cultural norms is well illustrated by Putnam who, in the 1970s, studied the performance of public agencies in different parts of Italy. Public entities in North and South Italy were guided by the same formal rules, however they varied by their socio-cultural context. Putnam came to the conclusion that efficiency of public agencies was higher in North Italy which had stronger traditions of horizontal civic bonds, i.e. civic engagement. At the same time, public organizations which performed in the context of South Italian society with undeveloped traditions of civic engagement suffered from intra organizational corruption. The case of South Italian public agencies distinctly correlates with the case of Georgian public organizations which also perform in conditions of undeveloped civic traditions.

Putnam binds concept civic engagement to historical traditions of social development in general and civil networks in particular. One of the main characteristics of a developed society are a high trust level between fellow citizens and less-hierarchical modes of governance which facilitate the establishment of civil networks. Thus, North Italian society was historically characterized by high trust levels among citizens, egalitarian patterns of interaction, and, on the other hand, the existence of civil networks as guilds, cooperatives, unions, sport clubs, literary societies, etc. At the same time, South Italian society was characterized by mutual distrust, vertical dependence, exploitation, social alienation, a high level of corruption and overall economic backwardness. With this connection, Putnam argues that research of public administration in heterogeneous society implies consideration of cultur- 
al context as a crucial factor which affects the overall performance of the object of study. He notes that the influence of culture and traditions equally spreads to all members of society even if they have a different social status. Thus, cultural heritage represents an omnipresent factor that conditions the behavior of actors whether in a formal or informal environment. "The performance of a representative of government is facilitated by the social infrastructure of civic communities and by the democratic values of both officials and citizens" (Putnam, 1993, p. 182).

The role of societal culture in the study of public administration is also emphasized by Karyeija. In studying performance evaluation in Uganda's governmental agencies, he refers to the cultural background of public servants who are in charge of policy implementation at the local level. According to Karyeija, there are two factors which determine effective policy implementation: (1) availability of technical resources and provision; and (2) attitudes of implementers, i.e. their mental model. Karyeija comes to the conclusion that adequacy of performance of local bureaucracy and consequently efficiency of policy implementation is closely related to the cultural values of implementers. He notes that the mental model of local bureaucrats plays a more decisive role in either success or failure of policy implementation than formal variables as resources and provisions. "The bureaucracy cannot be fully analyzed without underscoring the values, beliefs, norms, and attitudes that move it" (Karyeija, 2010, p. 5). According to Karyeija, there are two solutions that might facilitate the adaptation of Ugandan public servants to "borrowed" Western policies, and, consequently, increase the efficiency of policy implementation. The first resolution refers to the adjustment of borrowed policy to local "unique sets of values", and the second solution is to encourage local civil servants to "unlearn their current values and adopt the new value system" (Karyeija, 2010, p. 212).

Persson et al. acknowledge a correlation between failure of policy implementation and cultural factors. While studying the phenomenon of permanent corruption in Africa he came to the conclusion that the main failure of international anticorruption policies refers to their disregard of cultural settings of local developing societies. Specifically, international authors of anticorruption reforms do not consider cultural variations across societies where acceptance of corruption significantly varies. Therefore, policy based on the principle "one-size-fits-all" proves its inefficiency. For the improvement of the current state of affairs, developing societies need a so-called "big push" which implies reconsideration of norms of behavior on an institutional level. Person et al. outline two domains which need reconsideration: formal political and informal societal norms. According to them, "big push" is necessary primarily on an informal societal level that implies the formation of a culture of reciprocity and trust among local actors. At the same time, Persson et al. note that current anticorruption reforms are mainly oriented to the legal, i.e. formal (monitoring and punish) side of the issue. This strategy is inefficient because when societal culture contradicts formal arrangements proposed by the anticorruption policy, then the latter becomes "mere façade" (Persson et al., 2012, p. 466). "Endemic corruption is not some flaw that can be corrected with a technical fix or a political push. It is the way the system works and it is deeply embedded in the norms and expectations of political and social life. Reducing it to less destructive levels - and keeping it there - requires revolutionary change in institutions" (Diamond in Persson et at., 
2012, p. 465). According to Persson et al., resistance to corruption requires collective action from a part of society. At the same time, classic principal-agent theory being promoted by the authors of anticorruption policies, which refers to a monitoring and punishment model, is powerless when there is the absence of collective will. Persson et al. argue that in conditions of absence of collective will, no one performs as principal either to monitor or punish as the current status-quo is determined by cultural norms and is acceptable for all actors. In such a situation, elites continue being corrupt, and the others are given a chance to survive by struggling for the crumbs that fall from the "masters' table". The paradox of this situation is that "the others" would behave in the same corrupt way if they were given the chance (Persson et al., 2012, p. 458).

\section{Research design}

The literature recommends studying public administration of developing societies through three temporal levels. Those levels are: (1) institutional level which implies analysis of politico-administrative traditions of study object; (2) structural level that studies public administration in context of societal culture and historical legacy; and (3) interactional level that refers to definition of current challenges and their causal covariation with the past experience (Ekiert \& Hanson, 2003; Meyer-Sahling et al., 2011). The primary objective of my study was to analyse Georgian public administration through institutional and structural levels. Trying to touch upon both study levels, I focused mainly on the structural (societal) level which is considered as a main determinant of issues in Georgian public office. A study of structural level offers the possibility for a comprehensive explanation of the challenges existing in Georgian public office due to local societal traditions. Thus, qualitative research was dedicated to (a) societal traditions of in-group and out-group relations, (b) civic participation level, (c) the role and perception of the leadership in local society, (d) the doctrine of the Georgian orthodox church and its influence on societal life. Identification of the factors that supposedly correlate with the challenges of Georgian public administration (interactional level) provided variables that were used during the second stage of the study which implied a survey of Georgian public employees.

\section{Units of Analysis}

The Labor Code of Georgia defines the following types of public employees in Georgia: (a) public political officials who are either elected or assigned; (b) public servants, i.e. appointed bureaucrats, who represent the "backbone" of public organizations and who are divided into two groups: those who serve at the central (governmental) level and those who serve at the local level; (c) supplementary staff who provide technical support to public organizations and who are not involved in office work; and (d) freelance/supernumerary staff who work in public organizations on the basis of temporary contracts and who might perform as both office worker and supplementary employee (Dolidze et al., 2010). Units of analysis of the study were public servants employed in Georgian public agencies at the central governmental level. 
Due to bureaucratic obstacles and overall inaccessibility of Georgian public entities, the only feasible opportunity to conduct a survey was to address a mediator. The mediator I addressed was an employee in the press centre of the Administration of the Government of Georgia. The mediator was responsible for (a) random distribution of the questionnaires among employees of Georgian public entities through their email, and (b) for forwarding the completed questionnaires to me.

A total of 82 questionnaires were distributed and 50 random respondents employees of twelve public entities - participated in the survey. Twenty-seven of the respondents were employees at the Administration of Georgian government. This group of respondents represented about $10 \%$ of the overall number of employees at the Administration of Georgian government. Twenty-three of survey participants represented various public agencies of the country. This group of the respondents cannot be considered representative due to the absence of enough participants and a wide enough range of public entities they represented. The main goal of the survey was to retrieve as many completed questionnaires as possible, and as equally as possible from two age groups representing (a) so-called "old" $(41<)$ and (b) "new" (21-40) generations of Georgian public servants. Overall, this objective was achieved only partly as questionnaires filled-in by age group " $21-40$ " prevailed over questionnaires filled-in by age group " $41<$ " in a ratio of 76:24. The survey was conducted in January-April 2017.

Table 1

\section{Public entities that participated in the survey}

\begin{tabular}{|l|c|c|}
\hline \multicolumn{1}{|c|}{ Public entities } & Completed copies & Sent copies \\
\hline Administration of Georgian government & 27 & 27 \\
\hline Ministry of Health, Labour and Social Affairs & 4 & 5 \\
\hline Ministry of Foreign Affairs & 3 & 5 \\
\hline Ministry of Sport and Youth Affairs & 2 & 5 \\
\hline Ministry of Education and Science & 2 & 5 \\
\hline Ministry of Defence & 2 & 5 \\
\hline Ministry of Finance & 2 & 5 \\
\hline Ministry of Reconciliation and Civic Equality & 2 & 5 \\
\hline Ministry of Euro-Atlantic integration & 1 & 5 \\
\hline Ministry of Culture and Monument Protection & 1 & 5 \\
\hline Ministry of Internally displaced persons & 1 & 5 \\
\hline Ministry of Economy and Sustainable Development & 2 & 5 \\
\hline
\end{tabular}

Source: Compiled according to the calculations of the author (- hereafter, unless otherwise stated).

\section{Independent and Dependent Variables}

As independent variables of the study, I considered (1-2) social demography (gender and age), (3) place of birth (capital city/province), (4) presence of foreign 
education, (5) work experience in Europe/United States, (6) social background, such as occupation of parents, (7) attachment to family, and (8) religious affiliation. Dependent variables of the inquiry were composed on the basis of factual findings retrieved during qualitative research. Besides, for conceptualization of the variables, I addressed Hofstede's theoretical assumptions. Jamil's studies of the public administration system in Bangladesh played a significant role in the formation of the questionnaire. In addition, in the questionnaire I applied dependent variables from the report of Arasli and Tumer (2008) who studied the level of favouritism in organizations in North Cyprus. The questionnaire consisted of three main indexes (power distance index, collectivism-individualism index, uncertainty avoidance index) and three additional ones (elitism-egalitarianism index, nepotism-favouritism index, cronyism index) which performed as complementary sources of information and were incorporated with the main indexes. Namely, the Elitism-egalitarianism index was incorporated with the Power distance index, and the Nepotism-favouritism and Cronyism indexes were incorporated with the Collectivism-individualism index. The uncertainty avoidance index - which measured cultural rigidity of survey participants - was not combined with any other additional index. Total number of dependent variables of the survey was 36 .

Each section of the questionnaire was developed on the basis of observable implications. This point refers to King et al.'s concept of quality of data-generation that ultimately provides veracity of descriptive and causal inferences of the study. According to this notion, a prerequisite of reliability of quantitative study is a relevance of "specific questions that were asked" (King et al., 1994, p. 23). The process of formulation of the statements (questions) of the questionnaire was divided into three stages: (a) selection of theoretical framework in accordance with research questions (hypotheses), (b) identification and selection of observable implications consistent with the theoretical framework, and (c) collection of data about identified observable implications that means a choice of the most relevant variables. As a result, the elaborated questionnaire represents an instrument which provides data on the object under study either falsifying initial hypotheses or building strong evidence for them.

\section{Empirical Data Analysis}

Data analysis was carried out by means of the software package IBM SPSS Statistics. Statistical analysis involved percentages and mean scores. Each statement of the questionnaire included four possible answers: "completely agree", "agree", "disagree", or "strongly disagree". Each answer was labelled by a corresponding value ranging from " 1 " for "completely agree" to " 4 " for "strongly disagree". The questionnaire results were coded with a view to make them clear for the software facilitating consequent analysis. Analysis of empirical data was divided in three phases: (1) the first phase involved percentage frequency distribution according to survey responses; (2) the second phase implied definition of a central tendency of distribution, i.e. definition of mean scores; and (3) the third stage of statistical analysis implied cross-tabulation that allowed a comparison of correlation between variables. 
Table 2

\section{Distribution of the respondents according to categories}

\begin{tabular}{|c|c|c|c|}
\hline Independent variables & $\%$ & Independent variables & $\%$ \\
\hline $\begin{array}{l}\text { Age: } \\
21-40 \\
41 \text { and above }\end{array}$ & $\begin{array}{l}76 \\
24\end{array}$ & $\begin{array}{l}\text { Occupation of parents } \\
\text { Public sector } \\
\text { Private sector } \\
\text { Academic sector }\end{array}$ & $\begin{array}{l}30 \\
40 \\
30\end{array}$ \\
\hline $\begin{array}{l}\text { Gender } \\
\text { Female } \\
\text { Male }\end{array}$ & $\begin{array}{l}60 \\
40\end{array}$ & $\begin{array}{l}\text { Living while studying at the university } \\
\text { With parents } \\
\text { Separately }\end{array}$ & $\begin{array}{l}80 \\
20\end{array}$ \\
\hline $\begin{array}{l}\text { Place of birth } \\
\text { Capital city } \\
\text { Other }\end{array}$ & $\begin{array}{l}72 \\
28\end{array}$ & $\begin{array}{l}\text { Study experience in Europe, USA } \\
\text { One semester } \\
\text { One semester or more } \\
\text { No }\end{array}$ & $\begin{array}{l}16 \\
24 \\
60\end{array}$ \\
\hline $\begin{array}{l}\text { Religion } \\
\text { Georgian orthodox church } \\
\text { Other } \\
\text { Atheist }\end{array}$ & $\begin{array}{c}92 \\
4 \\
4\end{array}$ & $\begin{array}{l}\text { Work experience in Europe, USA } \\
\text { Several months } \\
\text { One year or more } \\
\text { No }\end{array}$ & $\begin{array}{l}22 \\
24 \\
54\end{array}$ \\
\hline $\begin{array}{l}\text { Type of position } \\
\text { High: deputy secretary and above } \\
\text { Medium: above assistant and below } \\
\text { deputy secretary } \\
\text { Low: assistant secretary and below }\end{array}$ & $\begin{array}{l}62 \\
24\end{array}$ & $\begin{array}{l}\text { Academic degree } \\
\text { Doctor } \\
\text { Master } \\
\text { Bachelor }\end{array}$ & $\begin{array}{l}10 \\
54 \\
36\end{array}$ \\
\hline $\begin{array}{l}\text { Years in service } \\
1-4 \\
5-10 \\
11 \text { and above }\end{array}$ & $\begin{array}{l}66 \\
12 \\
22\end{array}$ & $\begin{array}{l}\text { Had you either relative, friend } \\
\text { or acquaintance in the organization } \\
\text { before taking office? } \\
\text { Yes } \\
\text { No }\end{array}$ & $\begin{array}{l}76 \\
24\end{array}$ \\
\hline $\begin{array}{l}\text { Expected years in service } \\
\text { If I am lucky, then several years } \\
\text { It is difficult to predict } \\
\text { Hopefully, till retirement }\end{array}$ & $\begin{array}{c}4 \\
90 \\
6\end{array}$ & & \\
\hline
\end{tabular}

\section{Discussion of the survey findings}

\section{Finding 1: Servants as Potential Despots}

The main conclusion that might be made on the basis of the survey is that Georgian public servants do not consider the phenomenon of power concentration as an "issue" at all. Thus, $90 \%$ of survey participants correlate the concepts of "strong" and "governor" with each other. In other words, there is demand for a strong, powerful, dominating superior who would perform from a "topdown" position. Besides, Georgian public employees themselves might be identified as elitists. They are tolerant to such concepts as "subordination", "hierarchy" and "inequality". Thus, $86 \%$ of respondents agreed that supremacy 
of superiors inside an organization is an expected and positive phenomenon because their subordinates have not enough intellectual capacities to comprehend complexities of management. At the same time, $42 \%$ of public servants think that due to intellectual imperfection of the population they should not have the opportunity to influence authorities' decisions. Consequently, the ingrained societal tradition of subordination and even subjugation, and, on the other hand, domination are tracked quite distinctively among respondents. Moreover, those who are in subordinate positions themselves show predisposition to elitism regarding "commoners". Thus, 66\% of respondents considered existing in their office hierarchy as an objective phenomenon; and 74\% of respondents agreed that a "deep respect" for superiors should exist in their organizations. These points refer to Schramm's notion of closed organization where employees manifest either as "puppets" or as "good soldiers" of their superiors (Schramm, 2004). It should be noted that the level of acceptance of hierarchy is equal among young (65\%) and senior bureaucrats (66\%). Further, 58\% of survey participants agreed that in their offices, the superior's sympathy towards subordinates is more important than employees' professional skills. Sympathy of a superior as a decisive factor in bilateral interaction is emphasized by $60 \%$ of males and $56 \%$ of females. Overall, $52 \%$ of respondents acknowledged that there is no consultative interaction between them and their superiors. At the same time, only $6 \%$ of respondents are not satisfied with the style of interaction between superiors and subordinates.

On the other hand, despite the perception of existing authoritarianism as a matter of fact, Georgian public employees have a need for participation. In other words, having recognized and not contesting the supremacy of the "head of the family", nevertheless, subordinates want to be beneficial to the common business. Thus, only $30 \%$ of respondents agreed that the office is not a place for discussions with superiors, and only $18 \%$ of survey participants try to avoid giving their opinion to superiors. Moreover, 74\% of respondents are tolerant of the freedom of realization of ideas. Among those $26 \%$ who tend to restrict realization of ideas are $46 \%$ males and $54 \%$ females. Thus, females appeared to be more restrictive than male public servants. Moreover, young bureaucrats are more restrictive $-77 \%$, than seniors $-23 \%$.

Table 3

Power distance index and Elitism-egalitarianism index

\begin{tabular}{|l|l|l|}
\hline \multicolumn{1}{|c|}{ Index } & Agree & Mean \\
\hline \multicolumn{1}{|c|}{ Power distance index } & 66 & 2,3 \\
\hline Hierarchy in your organization is a reflection of employees' qualification & 74 & 2,3 \\
\hline There is a deep respect for superiors in your organization & 30 & 3,1 \\
\hline Workplace is not an arena for disputes with superiors & 52 & 2,6 \\
\hline $\begin{array}{l}\text { Superiors rarely ask you for your opinion } \\
\text { At the office personal sympathy of your superior towards you is more important } \\
\text { than your professionalism }\end{array}$ & 58 & 2,4 \\
\hline Are you satisfied with the quality of interaction between you and your superior? & 78 & 2,2 \\
\hline
\end{tabular}




\begin{tabular}{|c|c|c|}
\hline Index & Agree & Mean \\
\hline \multicolumn{3}{|l|}{ Elitism-egalitarianism index } \\
\hline $\begin{array}{l}\text { Certain people are better qualified than others to lead the country because } \\
\text { of traditions of their families }\end{array}$ & 30 & 3,0 \\
\hline Georgia needs strong personalities who know how to govern this country & 90 & 1,4 \\
\hline $\begin{array}{l}\text { Most citizens are not familiar with complexities of modern politics and even } \\
\text { during elections are unable to make an intelligent choice }\end{array}$ & 86 & 1,6 \\
\hline $\begin{array}{l}\text { Due to incompetence of most of citizens, they should not have the opportunity } \\
\text { to influence authorities' decisions }\end{array}$ & 42 & 2,9 \\
\hline A citizen should not realize his/her idea if it is unacceptable for others & 26 & 3,1 \\
\hline
\end{tabular}

Notes: High power distance and elitism involve the responses "completely agree" and "agree" while low power distance and egalitarianism imply the responses "disagree" and "strongly disagree" (not represented in the table).

The first column represents the cumulative percentage of those who either "completely agree" or "agree" with the statement.

Mean score ranges from 1 to 4: "one" involves high power distance and elitism, "four" involves low power distance and egalitarianism.

\section{Finding 2: Organization as a Neighbourhood}

The majority of survey participants (96\%) acknowledged that they wish and tend to unite around superiors, perceiving them as designers of action plans for subordinates (in contrast with written law or jointly elaborated strategy). The same mechanism works on a societal level where the head of the household performs as a guide distributing sporadic directives to family members. Moreover, Georgian public employees expect family relationships with each other. Thus, $66 \%$ and $64 \%$ of respondents respectively claim that without close and warm relationships, efficient performance of their organization is unlikely. The survey participants also try to avoid competition with each other as it might impact warm relations. Thereby, one of the fundamental pillars of market economy as a competition is perceived by $68 \%$ of Georgian public employees as a certain threat. However, despite declaring "family relationships" as a basis of intra-organizational culture, there is an intrinsic feeling of distrust among respondents. This point probably refers to the absence of tradition of joint cooperation in Georgian society when individuals without kinship ties (either relationship, friendship, acquaintanceship) cannot perform within one business association and experience difficulties in establishment of out-of-group relations.

Thus, the phenomenon of distrust might be explained by traditional intolerance to "strangers"; either they are representatives of another (a) household, (b) region (referring to historical division on principalities), (c) philosophical views or (d) religion. Moreover, under "strangers", along with foreigners, they might be equally considered members of Georgian society. Thus, 78\% of Georgian public employees believe that there are "disloyal groups" within Georgian society who perform to the detriment of common national interests and, at the same time, in favour of "foreign enemies". Further, $88 \%$ of respondents claim that loyal citizens should unite and face "traitors". Moreover, $88 \%$ of respondents are ready 
to forget their private interests, either to fight enemies or if there is a national interest at stake. The level of suspicion regarding "disloyal groups" among male respondents is $80 \%$, among females $-76 \%$. The level of militancy against "traitors" among males is $90 \%$, among females $-86 \%$. As for the level of dedication to common business, among males it is $85 \%$, among females it is even higher $-90 \%$. These indicators, in combination with employees' reverent obedience before superiors, distinctly outline the structure of narrow collectivism in Georgian society in general and in local organizations particularly.

Thus, in Georgian public organizations there are two objects of trust: the head of the group (referring to societal culture: the head of the family), and loyal members of the group (or those who correspond to the definition "members of family", i.e. a narrow circle of familiar personalities). At the same time, the data showed that there is always a risk of having "traitors" in the group (i.e. in the neighbourhood) who represent "disloyal groups" and who cannot be identified as family members. Therefore, in Georgian public organizations, despite the priority of "close and warm relations", there is certain distrust and probably tension between employees that hinder teamwork. As a result of such a tendency, $74 \%$ of respondents evaluate public briefings negatively, and show a preference for tete-a-tete communication with superiors. According to respondents, either public appraisal or criticism might cause disharmony in their organizations. In addition, in Georgian public organizations there is somewhat a tendency to alienate external supervision. More than half, $52 \%$ of survey participants prefer to keep issues inside their offices.

Regarding the issues of nepotism, favouritism and cronyism, which apparently correlate with the concept "organization as a family", there is a certain parity between those who acknowledge the existence of nepotism and favouritism in their organizations (48\%) and those who consider their offices to be free of such practices (52\%). Along with acknowledgement of the existence of nepotism and favouritism, respondents emphasized that illegal schemes are somewhat decisive in long-term employment (30\%), career advancement (38\%), and overall security of position (46\%). Almost half of the respondents (46\%) also believe that nepotism and favouritism play a destructive role for the organization. The same parity arises regarding the phenomenon of cronyism. Only $48 \%$ of respondents bound appointment to the office, promotion or reward of employees with their political affiliation. However, a moderate level of nepotism and cronyism seems paradoxical as it creates a discrepancy with other retrieved data. Thus, according to $76 \%$ of respondents, before taking office they already had either a relative, friend or acquaintance in the organization.

Generally, on the basis of the survey it can be argued that the role of political affiliation in Georgian public administration is more significant than other forms of favouritism. Thus, $66 \%$ of respondents pointed out that they have been in service during the last 1-4 years, i.e. they took their offices after the changing of political power in the country in 2013 , and $84 \%$ of them had "either a relative, friend or acquaintance in the organization" before their appointment. Moreover, $63 \%$ of them had already held a type of secondary position in their departments. At the same time, only 12\% of employed public servants in 2017 had 
been appointed in the period of previous political power (2004-2013). Meanwhile, $22 \%$ of survey participants represent the political power which governed the country before the 2003 revolution. Thus, there is a distinct tendency for labour turnover in Georgian public organizations after a change in political leadership. In support of this point, $76 \%$ of survey participants agree that the change of the head of the ministry "had influence on either the recruitment or promotion of employees"; 74\% of respondents show apprehension of losing office in the case of change of political leadership; and $82 \%$ agree that it is unusual in their organizations to talk about previous political leaders. Besides, $90 \%$ of respondents cannot predict how many years they will be in service apparently as many years as their superiors.

Table 4

\section{Collectivism-individualism, nepotism-favouritism and cronyism indexes}

\begin{tabular}{|c|c|c|}
\hline Index & Agree & Mean \\
\hline \multicolumn{3}{|l|}{ Collectivism-individualism } \\
\hline $\begin{array}{l}\text { Relationship between members of organization should be akin to relationship } \\
\text { of friends or relatives }\end{array}$ & 66 & 2,3 \\
\hline $\begin{array}{l}\text { Without warm relationship between members of organization effective } \\
\text { performance is unlikely }\end{array}$ & 64 & 2,1 \\
\hline For effective performance members of organization should unite around superior & 96 & 1,3 \\
\hline $\begin{array}{l}\text { Appraisal or the criticism of an employee in presence of others might cause } \\
\text { deterioration of working process }\end{array}$ & 74 & 1,9 \\
\hline Competition between members of organization causes negative effects & 68 & 2,2 \\
\hline $\begin{array}{l}\text { Results of performance should be evaluated inside public entity without } \\
\text { supervision of civil organizations or NGOs }\end{array}$ & 52 & 2,5 \\
\hline $\begin{array}{l}\text { There always have been and currently are non-patriotic groups in Georgia who } \\
\text { contribute to our ill-wishers }\end{array}$ & 78 & 1,7 \\
\hline In the matter of facing our enemies we should be united & 88 & 1,4 \\
\hline There is no an individual interest when we talk about common business & 88 & 1,4 \\
\hline \multicolumn{3}{|l|}{ Nepotism-favouritism index } \\
\hline $\begin{array}{l}\text { For long-term employment in your organization it is desirable to have a relative, } \\
\text { friend or acquaintance }\end{array}$ & 30 & 3,1 \\
\hline Having a relative, friend or acquaintance would make your position safer & 40 & 3,0 \\
\hline Having a relative, friend or acquaintance would promote career advancement & 38 & 3,0 \\
\hline Employment through corrupt schemes is a common practice in your organization & 48 & 2,6 \\
\hline $\begin{array}{l}\text { Executives of the ministry rarely fire or demote friends and acquaintances even } \\
\text { if they prove to be inadequate }\end{array}$ & 46 & 2,6 \\
\hline $\begin{array}{l}\text { Colleagues who are employed on the basis of nepotism influence negatively } \\
\text { on an organization }\end{array}$ & 46 & 2,6 \\
\hline
\end{tabular}




\begin{tabular}{|c|c|c|}
\hline Index & Agree & Mean \\
\hline \multicolumn{3}{|l|}{ Cronyism index } \\
\hline $\begin{array}{l}\text { In your organization political affiliations of the employees are bound to their } \\
\text { appointment, promotion, or provision of other privileges }\end{array}$ & 48 & 2,7 \\
\hline $\begin{array}{l}\text { Changes in political leaders and ministers influence either recruitment } \\
\text { or promotion of the employees }\end{array}$ & 76 & 2,1 \\
\hline Changes in political leaders and ministers cause apprehensions of losing office & 74 & 2,1 \\
\hline $\begin{array}{l}\text { It is unusual in your organization to talk (out of working hours) about successful } \\
\text { performance of previous government }\end{array}$ & 82 & 1,8 \\
\hline
\end{tabular}

Notes: (a) Narrow collectivism, (b) recognition of existence of cronyism and its negative influence, (c) recognition of existence of nepotism and its negative influence involved responses "completely agree" and "agree" while (a) inclination to individualism, (b) absence and tolerance to cronyism and (c) nepotism implied responses "disagree" and "strongly disagree" (not represented in the table).

The first column represents the cumulative percentage of those who either "completely agree" or "agree" with the statement.

Mean score ranges from 1 to 4: "one" involves predisposition to narrow collectivism, existence of cronyism and nepotism, "four" involves predisposition to individualism, absence of cronyism and nepotism.

\section{Finding 3: New Generation - Old Mentality}

Soon after the revolution in 2003, the state ministry for Euro-Atlantic integration was established in Georgia. The main purpose of the ministry became promotion of Euro-Atlantic values and the development of strategies for integration with the European Union and North Atlantic Treaty Organization. The latest achievement of the ministry was visa liberalisation for Georgian citizens visiting the European Union. As a final objective, the ministry desires for the country membership of the EU and NATO. Thus, during the last decade, Georgian society has lived under conditions of large-scale propaganda of EuroAtlantic (i.e. Western) values. For the eradication of "remnants of the past" there is a state-level program of "rejuvenation" of the public administration system. According to state policy, representatives of the new generation have an advantage over their senior fellow citizens during recruitment into public agencies. Moreover, in accordance with the rejuvenation program, the minimum candidacy age for membership of parliament in the country was lowered to 21 years. Along with the age, during recruitment those applicants are prioritized who have work or study experience either in Europe or the USA. Results of the state-level program of rejuvenation of Georgian public servants is well depicted in this survey. Thus, $76 \%$ of survey participants were aged $21-40$, while only $24 \%$ represented the age span of " 41 and above". Moreover, $48 \%$ of "juniors" held a medium type of position (that is above assistant secretary and below deputy secretary), being appointed to the positions soon after employment.

At first sight, the decade of the intensive introduction of Western values in Georgia was quite productive. As the survey showed, $96 \%$ of Georgian public employees agree that sooner or later Georgia will adopt Western democratic values. Moreover, $100 \%$ of "seniors" representing the age group " 41 and above" supported the idea of the implementation of Western democratic values in Georgia, while $94 \%$ of "juniors" representing the age span " $21-40$ " endorse democratiza- 
tion of the country. The adoption of democratic values is supported by the overwhelming majority of public servants, both those who either studied or worked in Europe. At the same time, during the survey a paradoxical phenomenon was identified: $92 \%$ of respondents agreed that despite integration to Europe, Georgians should stick to their centuries-old traditions. The majority of juniors agreed with the maintenance of traditionalism - 89\%, while living according to centuries-old traditions was supported by $100 \%$ of seniors. In this regard, I can argue that liberalization of Georgian public servants is a somewhat illusory phenomenon occurring on the superficial level of absorption of propaganda, while their traditional, ingrained values remain unchangeable. Thus, on the one hand, respondents have absorbed messages of intensive propaganda of Western values; on the other hand, they do not distinguish substantial contradictions between Western "democratic values" and "centuries-old traditions" of their own society. Moreover, as the survey showed, neither study nor work experience in Western countries has an influence on the "modernization" of Georgian bureaucrats. Thus, $85 \%$ of those having study experience either in Europe or the United States agreed with the maintenance of Georgian societal traditions, while $91 \%$ of those having work experience abroad agreed with the necessity of observation of centuries-old traditions despite integration to the European Union. This might be a distinct sign that for Georgians, including representatives of the younger generation, a Western lifestyle is less attractive, or not attractive at all.

During qualitative discourse I identified the Georgian orthodox church as a social institute that might be called the main source of traditionalism for the local population. The same conclusion can be made following the survey of Georgian public servants. The absolute majority of survey participants, $92 \%$, identified themselves as members of the Georgian orthodox church, $4 \%$ as atheists, and $4 \%$ as representatives of "other religions". Further, $84 \%$ of respondents considered orthodox Christianity as a foundation of the Georgian nation despite the existence of a variety of political and philosophical ideas. The Orthodox religion is perceived as a "pillar of the nation" by $84 \%$ of young bureaucrats; the same trust level exists among senior public servants $-83 \%$. Despite the religiosity and even fanaticism of Georgian society, $62 \%$ of respondents think that Georgians, especially the new generation, still need strengthening of faith. The call for the strengthening of religiosity is more distinct among senior bureaucrats $-83 \%$, while this idea is shared only by $55 \%$ of young bureaucrats. At the same time, there is a certain feeling of protest against the Georgian orthodox church among respondents of both age groups. Thus, only $42 \%$ of survey participants consider a reduction of the influence of the Georgian orthodox church as an equivalent to losing national identity. Less influence by the church is considered as a threat by $47 \%$ of public servants of the age span 21-40, while among seniors the figure is $58 \%$.

Despite certain protests against the church as a social institution, it can be argued that Georgian bureaucrats reflect religious ideology promoted by the Georgian orthodox church. As a measure of the susceptibility of Georgian public servants to religious rhetoric, in the survey I referred to the concept of "God's chosen people". This concept is well ingrained among the population, being part of the "national consciousness" of Georgians. Legends about the divine origina- 
tion of the Georgian nation have been introduced not only by religious literature and orthodox priests, but also by the school program, local intellectuals and even politicians who normally use these ideas to attract voters. In the questionnaire, the same word order is used as it is used in daily life in Georgia among ordinary citizens. As a result, $62 \%$ of survey participants agreed with the statement "the Georgian nation is chosen by Mother of God". This high level of agreement is surprising if we take into account, on the one hand, the archaism of the statement, and, on the other hand, the high level of education of the respondents. Among young public servants the agreement rate was 58\%, while among the old generation of bureaucracy it was 75\%. Among those who "have seen the world", the agreement rate was unexpectedly high. Also in agreement with the statement were $75 \%$ of those having study experience abroad, and $78 \%$ of those having work experience abroad. The most zealous apologists of the concept of the divine origination of Georgians are respondents whose parents represent the academic sector $-86 \%$, while less fanaticism was shown by representatives of the private sector $-55 \%$, and the public sector $-46 \%$. Paradoxically, 50\% of atheist respondents also agreed with the idea of the divine origination of the Georgian nation. Another peculiarity is the prevalence of supporters of "Georgian exceptionalism" among those born in the capital city - 70\%, while among public servants born in the province adherents of the idea of exceptionalism was $42 \%$.

Table 5

\section{Uncertainty avoidance index}

\begin{tabular}{|l|c|c|}
\hline \multicolumn{1}{|c|}{ Uncertainty avoidance index } & Agree & Mean \\
\hline Sooner or later Georgia will become carrier of democratic values & 96 & 1,2 \\
\hline $\begin{array}{l}\text { Despite integration with Europe we should stick to our centuries-old traditions } \\
\begin{array}{l}\text { Despite the variety of political and philosophical ideas orthodoxy is still the basis } \\
\text { of our nation }\end{array}\end{array}$ & 84 & 1,7 \\
\hline We, and especially the new generation, need to strengthen our faith & 62 & 2,3 \\
\hline Reduction of influence of the church is bound to loss of national identity & 42 & 2,9 \\
\hline The Georgian nation is chosen by Mother of God & 62 & 2,2 \\
\hline
\end{tabular}

Notes: Strong societal traditionalism and stereotypes involves responses "completely agree" and "agree", while inclination to renovations implies responses "disagree" and "strongly disagree".

The first column represents the cumulative percentage of those who either "completely agree" or "agree" with the statement.

Mean score ranges from 1 to 4: "one" involves traditionalism and stereotypical thinking, "four" involves predisposition to renovations.

\section{Finding 4: There are Modernizers}

At the current stage of the transformation of Georgian society, it is impossible to talk about noticeable cultural variation among the survey participants. Both the old and new generations of Georgian public servants share the same values and attitudes quite evenly. Moreover, based on data analysis, I came to the conclusion that in some points representatives of the new generation show more 
traditionalism than their senior colleagues. Thereby, the younger generation can hardly be considered as the proponent of "the westernization" of Georgian society; rather, they feel comfortable within the existing social order:

- $\quad 92 \%$ of young public servants need strong managers, while similar demand for authoritarianism was expressed by $83 \%$ of senior bureaucrats

- $\quad 74 \%$ of juniors believe that relations between fellow workers should resemble kinship, while only $33 \%$ of seniors share this opinion

- $\quad 100 \%$ of young public servants proclaimed superiors as key figures in the organization and considered it necessary to unite around them, while seniors showed more independence $(83 \%)$ partly sharing the perceptions and needs of their younger colleagues

- $\quad 79 \%$ of young bureaucrats negatively assessed public briefings, preferring tete-a-tete communication with superiors, while $66 \%$ of seniors have the same opinion

- $\quad 73 \%$ of juniors consider fair competition between fellow workers as a destructive phenomenon, while this opinion was shared by $50 \%$ of seniors

- $\quad 92 \%$ of young public servants are ready to unite against enemies, while militancy was showed by $75 \%$ of those representing the age group " 41 and above"

- $\quad 84 \%$ of juniors are sure about the existence of traitors in Georgian society, while this belief is shared by $58 \%$ of senior bureaucrats

At the same time, Georgian bureaucracy should not be labelled as entirely homogeneous as it has been considered so far. As a subgroup of modernizers among young public servants, I can single out those who were born in the province but gained their education in the capital city. Most of these, while studying in the capital city, lived either alone or with fellow students in rented apartments separately from parents. Thus, $88 \%$ of public servants born in the capital city who represent the age group 21-40 lived with parents during study at university, while among respondents born in the province and representing the age group 21-40, the percentage of those who lived with parents was only 42 . The tendency to the somewhat modernity of those who lived independently is apparently determined by separation with their families. Thereby, after leaving the parental home, the family, which in Georgian society represents an important source of traditionalism, partly loses its influence on youths. As a result, those born in the province perceive an organization less as a family. The results obtained on the basis of cross-tabulation are the following:

- $\quad 50 \%$ of those born in the province believe that relationships between employees should be akin to relations between family members, while kinship relations are expected by $69 \%$ of those born in the capital city and living/having lived with parents

- $\quad 36 \%$ of those born in the province are tolerant to public criticism, while public briefings were positively perceived only by $20 \%$ of those born in the city and living/having lived with parents

Further, employees from the province are more critical regarding the existing hierarchy inside the organization. According to $50 \%$ of them, hierarchy does not reflect employees' qualification, rather hierarchy is based on other criteria which are far from objectiveness. At the same time, $72 \%$ of those born in the city 
and living with parents perceive hierarchy as an objective phenomenon. Also, employees from the province showed less submission. Thus, only $14 \%$ of them think that the office is not a place for disputes with superiors, while discussion with superiors was unacceptable for $36 \%$ of those born in the city and living with parents. Further, respondents from the province showed somewhat less traditionalism and stereotypical thinking. They agreed with the statement that Georgia will inevitably adopt European values; however, unlike those born in the capital city, they are more sceptical about the preservation of local centuries-old traditions. If $97 \%$ of those born in the city believe that Georgia should keep its societal traditions even in spite of the adoption of Western values, then this opinion was shared by $78 \%$ of employees born in the province. Further inculcation of religiosity is supported by $72 \%$ of those from the capital city, while this idea was shared by $57 \%$ of those born in Georgian province. Besides, the concept of the divine origination of the Georgian nation, which is the most archaic and stereotypical belief in local society, was accepted by $42 \%$ of those born in the province, while this concept was supported by $70 \%$ of respondents born in the capital city.

Another group of somewhat modernizers are those public servants who represent academic families. They showed somewhat the modernity of attitudes regarding principles of office work and communication with fellow employees. At the same time, they showed rigidity of attitudes concerning societal traditions and stereotypes. Thus, only $46 \%$ of those from academic families believe that either family or friendly relations should prevail in an organisation, while $73 \%$ and $70 \%$ of those (whose families relate respectively to public and private sectors) expect family and friendly relations at office. In contrast to other groups, public servants representing academic families are more tolerant to public criticism and competition. Thus, 34\% of them assessed positively on briefings and public criticism in the workplace, while tolerance regarding criticism was shown by only $20 \%$ of their colleagues with a public and business social background. Competition is assessed as a positive phenomenon by $60 \%$ of those from an academic background, while competition is acceptable only for $20 \%$ of their colleagues with a public and business social background. At the same time, those from academic families showed generally more stereotypical thinking. Thus, $80 \%$ of them believe that Georgian society should be more religious, while this idea is supported only by $46 \%$ and $55 \%$ of their colleagues with a public and business social background. Besides, $86 \%$ of those who are from academic families accept the idea of the divine nature of the Georgian nation, while this concept is shared by $47 \%$ and $55 \%$ of those from a public and private social background. As for attitudes towards other variables, views of employees with academic, public and private social background coincided.

Tolerance of public criticism and competition of those representing academic families might be explained by the fact that $60 \%$ of them had no relatives, friends or acquaintances at the office before employment. So, they may be considered as those who acquired their offices through competition but not through patronage. Consequently, they are critical regarding the concept of "organization as a family" which implies the existence of informal networks. At the same time, $87 \%$ of those whose parents represent the public sector had either relatives, friends or acquaintances inside the office before being employed, while either relatives, 
friends or acquaintances had $80 \%$ of those whose parents represent the private sector. Thus, this data reveals those who are generally appointed to the office through informal schemes of employment. Firstly, those are public servants whose parents themselves represent the public sector (87\%), and, secondly, those from families representing private business (80\%).

In the aggregate, there are two variables which play an important role in the matter of modernization of Georgian public servants. The first variable is family, namely family separation. As the survey showed, those who lived and studied separately without influence from their families tend to be more modern in their attitudes towards religion, centuries-old societal traditions and social stereotypes. They also tend to perceive organization as a part of the business environment but not as a family. However, regarding other points they equally share the same attitudes as their colleagues from the capital city living with parents. The second variable which plays a positive role is competition. Those who acquired office through competition showed less tolerance regarding corruption at office. They tend less to perceive organization as "a family". Besides, they generally do not expect "close" and "warm" relations with colleagues, apparently because of the focus on job responsibilities but not on participation in informal networks. At the same time, acceptance of competition does not change traditional attitudes towards superiors. As with others, employees who acquired office through competition also showed a "deep respect" for superiors, they believe in dominating management, and tend to perceive superiors as designers of an action plan for subordinates. Moreover, those who were appointed through competition and who represent academic families actually share the same elitist views as their "corrupt" colleagues. Thus, $93 \%$ of them believe that Georgian citizens do not have enough intellectual capacities to make an intelligent choice during elections, while of the same opinion are $86 \%$ and $80 \%$ of those representing families with public and private social backgrounds respectively. In other words, those from academic families and those appointed through competition are positive about the phenomenon of power concentration.

\section{Conclusion}

The article drew a parallel between societal and administrative culture in Georgia. From the findings of the study, it can be concluded that societal traditions significantly determine such phenomena in Georgian public office as power concentration, patron-client relations, clanship and inability of teamwork which refer to the societal phenomena of high power distance and narrow collectivism. Consequently, the combination of high power distance and narrow collectivism create a phenomenon of vertical narrow collectivism which might be regarded as the main issue of both Georgian society and Georgian public office. At the same time, there is a subgroup of Georgian public servants who might be regarded as either partly modernizers or potential modernizers. Thereby, the study results disconfirm the common scientific assumption of homogeneity of Georgian bureaucracy. Another finding of the study is the identification of variables which play the role of "modernization" for Georgian public servants. The existence of a modern 
type of bureaucracy in Georgian public administration may indicate the existence of positive dynamics in the system. However, data analysis revealed irregularity of such dynamics conditioned by individual initiatives rather than by well-elaborated governmental policy².

The study also showed that the habit of Georgian society to blame others (historical background, foreign and internal enemies) for various failures should be regarded as destructive for Georgian society itself. Thus, the study revealed a groundless common opinion which blames the non-existing soviet system for persisting issues of Georgian public office. On the contrary, scientific evidence shows that in fact the phenomena of power concentration, patron-client relations, clanship, inability of teamwork have deep cultural roots which refer not to the soviet background, but to the centuries-old traditions of the Georgian people. Identification of such "little truths" implies the ability for seeing undistorted reality which may ultimately contribute to its improvement. However, such an approach requires certain cultural flexibility on the part of society: firstly, it requires critical and pragmatic analysis of existing reality, and, secondly, it requires cultural tolerance to changes. However, on the basis of the survey, a conclusion can be drawn that representatives of Georgian society (even the new generation) are generally conservative in their attitudes avoiding reconsideration of habitual reality. Consequently, the cultural rigidity of Georgian society seems to be one of the reasons that the cultural rigidity of Georgian society is one of the reasons why local public administration cannot adopt a Western model of organization and management but still applies traditional models of behaviour which are associated with corruption and inefficiency.

The findings of the study indicate that Georgian society needs a transformation of social institutions and models of behaviour which these institutions instil and promote. Those institutions are: family, church, and school, i.e. those which are involved in the initial stages of socialization of Georgian citizens. By means of empirical data analysis, it turns out to be evident that these social institutions instil destructive values and habits in individuals, and those values and habits do not contribute to modernization, i.e., the development of Georgian society.

\section{REFERENCES}

1. Albrow, M. (1970). Bureaucracy. New York: Praeger.

2. Alvesson, M. (2002). Understanding Organizational Culture. London: Sage Publications Ltd.

3. Arasli, H. \& Tumer, M. (2008). Nepotism, Favoritism and Cronyism: A Study of their Effects on Job Stress and Job Satisfaction in the Banking Industry of North Cyprus, Social Behavior and Personality, no 36, pp. 1237-1250. Available at: http://search.proquest.com/docview/ 209915742?OpenUrlRefId=info:xri/sid:primo\&accounti d=8579 (accessed: 14 April 2021).

\footnotetext{
2 Reference to those public servants-modernizers born in the province who left families to study in the capital city in accordance with their own initiatives but not following any student-oriented state policy.
} 
4. Bertelsmann Stiftung's Transformation Index (2016). Georgia Country Report. Gütersloh: Bertelsmann Stiftung. Available at: https://bti-project.org/content/en/downloads/reports/ country_report_2016_GEO.pdf (accessed: 14 April 2021).

5. Charkviani, T. (2014). Neopatrimonial and Meritocratic Managerial Strategies in the Transforming Civil Service (PhD thesis). Tbilisi: Ilia State University, pp. 122-180. Available in Georgian language at: http://eprints.iliauni.edu.ge/2967/1/1483\%20ossəsm\%20 hsm330s6o.pdf (accessed: 14 April 2021).

6. Dawa, N. (2002). Culture and the Politics of Third World Nationalism. London, New York: Routledge.

7. Della Porta, D. \& Vanucci, A. (1999). Corrupt Exchanges. Actors, Resources, and Mechanisms of Political Corruption. New York: Aldine de Gruyter.

8. Dolidze, N., Jobava, I., Sopromadze, E., Loladze, N., Loladze, T., Ovsiannikova, L., Antia, Zh., Mzhavanadze, G. \& Sonishvili T. (2010). Public Administration in Post-Communist Countries: Former Soviet Union, Central and Eastern Europe, and Mongolia. Boca Raton, London, New York: CRC Press.

9. Ekiert, G. \& Hanson, S.E. (2003). Time, Space and Institutional Change in Central and Eastern Europe. Available at: http://is.cuni.cz/studium/predmety/index.php?do=download\&did $=30031 \&$ kod=JPM522 (accessed 14 April 2021).

10. Ermisch, J. \& Gambetta, D. (2011). Do Strong Family Ties Inhibit Trust? Journal of Economic Behavior \& Organization, vol. 75, no 3, pp. 365-376. Available at: http://www.sciencedirect. com/science/article/pii/S0167268110000892 (accessed 14 April 2021).

11. Fukuyama, F. (2011). Political Order and Political Decay. From the Industrial Revolution to the Globalization of Democracy. New York: Farrar, Straus and Giroux.

12. Gotsiridze, R. \& Mukataridze A. (2014). Georgian elites and clans (electronic article). Tbilisi Times. Available at: http://www.ttimes.ge/archives/23695 (in Georgian) (accessed: 30 April 2021).

13. Hofstede, G. (2005). Culture and Organizations: Software of the Mind. New York, NY: McGraw-Hill, Two Penn Plaza.

14. Jamil, I. (2007). Administrative Culture in Bangladesh. Dhaka: A H Development Publishing House.

15. Kachkachishvili, I. (2014). Labour Culture and Religious Discourse in Various Communities. Paper Presented at the Heinrich Böll Stiftung South Caucasus Conference, 5 November 2014, Tbilisi, pp. 2-4. Available at: https://ge.boell.org/sites/default/files/uploads/2014/11/ labor_culture.pdf (in Georgian). (accessed: 30 April 2021).

16. Karyeija, G. (2010). Performance Appraisal in Uganda's Civil Service: Does Administrative Culture Matter? (PhD thesis). Bergen: University of Bergen, pp. 5, 212. Available at: http:// bora.uib.no/handle/1956/3953 (accessed: 30 April 2021).

17. King, G., Keohane, R.O. \& Verba, S. (1994). Designing Social Inquiry: Scientific Inference in Qualitative Research. Princeton, New Jersey: Princeton University Press.

18. Lippmann, W. (1991). Public opinion. New Brunswick, New Jersey: Transaction publishers.

19. Maisuradze, G. (2015). Little Imperialism and the Logic of Hegemony. Radio Free Europe Radio Liberty. Available at: https://www.radiotavisupleba.ge/a/giorgi-maisuradze-blogpost/27041804.html (in Georgian) (accessed: 30 April 2021). 
20. Mariamidze, G. (2014). Nothing Personal, it is Just Business. NetGazeti. Available at: https:// blogs.netgazeti.ge/2014/09/23/36194/ (in Georgian) (accessed: 30 April 2021).

21. Meyer-Sahling, J.-H. \& Yesilkagit, K. (2011). Differential Legacy Effects: Three Propositions on the Impact of Administrative Traditions on Public Administration Reform in Europe East and West. Journal of European Public Policy, vol. 18, no 2, pp. 311-322. Available at: DOI: https://doi.org/10.1080/13501763.2011.544515 (accessed: 30 April 2021).

22. Mindiashvili, B. (2013). Georgian Patriarchy as a Main Source of Lies about God and Human Being. New Press. Available at: http://newpress.ge/staties_id/523 (in Georgian) (accessed: 30 April 2021).

23. Mkheidze, Z. (2010). Infantile Society. PSnews. Available at: http://psnews.ge/index.php?m= 68\&news_id=14337 (in Georgian) (accessed: 30 April 2021).

24. Morrill, C. (2008). Culture and Organization Theory. The Annals of the American Academy of Political and Social Science, vol. 619, no 1, pp. 15-40. Available at: DOI: https://doi. org/10.1177\%2F0002716208320241 (accessed: 30 April 2021).

25. Nikoleishvili, M. (2014). Georgian Men are Socially Castrated. Versia. Available at: https:// for.ge/index.php/view/35410/qarTveli-mamakaci-socialurad-kastrirebulia.html (in Georgian) (accessed: 30 April 2021).

26. Nizharadze, G. (2015). Between Two Seas. Arili. Available at: http://arilimag.ge/zşs-

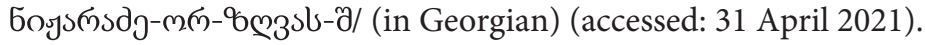

27. Papadoulis, K. (2006). Clientelism, Corruption and Patronage in Greece: A Public Administration Approach. Teaching Public Administration, vol. 26, no 1, pp. 13-24. Available at: DOI: https://doi.org/10.1177\%2F014473940602600102 (accessed: 31 April 2021).

28. Pavlova, I. (2014). Sotsial'no-istoricheskie predposylki obshchnosti ètnokul'tury narodov Povolzh'ia [The Socio-Historical Background of the Commonality of Ethnic Cultures of the Peoples of Volga Region]. Available at: http://cyberleninka.ru/article/n/sotsialnoistoricheskie-predposylki-obschnosti-etnokultury-narodov-povolzhya (accessed: 30 April 2021).

29. Persson, A., Rothstein, B. \& Teorell, J. (2013). Why Anticorruption Reforms Fail - Systemic Corruption as a Collective Action Problem. Governance, vol. 26, no 3, pp. 458, 465-466. Available at: DOI: https://doi.org/10.1111/j.1468-0491.2012.01604.x (accessed: 30 April 2021).

30. Putnam, R. (1993). Making Democracy Work. Princeton, New Jersey: Princeton University Press.

31. Rukhadze, V. (2016). Clanship System: One of the Reasons of Eternal Georgian Crisis. Ac-

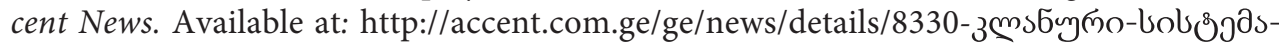

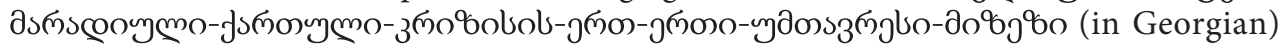
(accessed: 15 May 2017).

32. Shelley, L., Scott, E.R. \& Latta, A. (2007). Organized Crime and Corruption in Georgia. New York: Routledge.

33. Schramm, F. (2004). Open and Closed Organizations. 1st Edition. Available at: http://www. hr-network.hu/szolgaltatasok/open_and_closed_organizations.pdf(accessed:20January2017).

34. Shiukashvili, Kh. (2010). Apogee of Georgian Conformism. Available at: http://club.polit forumi.com $/$ index.php? showtopic $=9633 \&$ mode $=$ threaded \&pid $=251803$ (in Georgian) (accessed: 25 January 2017). 
35. Smith, D.J. (2007). A Culture of Corruption: Everyday Deception and Popular Discontent in Nigeria. Princeton, New Jersey: Princeton University Press.

36. Semyonova, A. (2011). O metodakh i sredstvakh vospitaniia zhenshchiny v traditsionnor̆ pedagogike narodov Severo-Zapadnogo Kavkaza [Methods of Upbringing in Traditional Pedagogics in the North Caucasus Region]. Novye tekhnologii, no 1. Available at: http:// cyberleninka.ru/article/n/o-metodah-i-sredstvah-vospitaniya-zhenschiny-v-traditsionnoypedagogike-narodov-severo-zapadnogo-kavkaza (accessed: 14 April 2021).

37. Smirnova, J. (1983). Sem'ia i semeynyi byt narodov Severnogo Kavkaza [Family and family life in the North Caucasus region]. Moscow: Nauka. Available at: http://www.elbrusoid.org/ upload/iblock/94f/94fbe75cfaaa0ce2f246fd1396b8b027.pdf (accessed: 14 April 2021).

38. Toria, Zh., (2015). Traditsionnye ustoi vospitaniia na Kavkaze: vchera, segodnia, zavtra [Traditional Training in the Caucasus: Prospects and Realities]. Available at: http://cyberleninka. $\mathrm{ru} /$ article/n/traditsionnye-ustoi-vospitaniya-na-kavkaze-vchera-segodnya-zavtra (accessed: 14 April 2021).

39. Tsiramua, M. (2015). Methods of Upbringing in Georgia. Liberali. Available at: http://liberali.ge/ articles/view/2385/aghzrda-qartulad (in Georgian) (accessed: 30 March 2017).

40. UNDP (2013). Public Perceptions on Gender Equality in Politics and Business. Tbilisi: UNDP Georgia. Available at: http://www.ge.undp.org/content/dam/georgia/docs/publications/GE_ UNDP_Gender_Research_GEO.pdf (in Georgian) (accessed: 14 April 2021).

41. Weber, M. (1992). Protestant Ethics and the Spirit of Capitalism. New York: Routledge.

42. Zabaev I. (2008). The Orthodox Ethics and the Spirit of Socialism (Supporting the Hypothesis). Philosophy and Society, vol. 23, no 1, p. 57. Available at: https://www.academia.edu/21987157/ THE_ORTHODOX_ETHICS_AND_THE_SPIRIT_OF_SOCIALISM_SUPPORTING_ THE_HYPOTHESIS (accessed: 14 April 2021).

\section{INTERVIEWS WITH:}

Antonova L., philosopher, Tbilisi State University;

Berdzenishvili A., sociologist, Tbilisi State University;

Bichikashvili I., journalist, Tbilisi State University;

Esebua F.K., sociologist, Ilia State University;

Maisashvili Kh., journalist, Tbilisi State University. 